\title{
Profil Berpikir Kreatif Siswa SMP dalam Menyelesaikan Masalah Matematika Kontekstual Berdasarkan Perbedaan Tipe Kepribadian Introvert dan Ekstrovert
}

\author{
Selvia Desi Ekayana, Didik Hermanto, Moh Affaf
}

(C) 2020 JEMS (Jurnal Edukasi Matematika dan Sains)

This is an open access article under the CC-BY-SA license (https://creativecommons.org/licenses/bysa/4.0/) ISSN 2337-9049 (print), ISSN 2502-4671 (online)

\begin{abstract}
Abstrak:
Penelitian ini bertujuan untuk mendeskripsikan profil berpikir kreatif siswa SMP dalam menyelesaikan masalah matematika kontekstual berdasarkan tipe kepribadian introvert dan ekstrovert. Penelitian ini merupakan penelitian deskriptif kualitatif. Subjek penelitian terdiri dari siswa perempuan berkepribadian introvert dan siswa perempuan berkepribadian ekstrovert. Instrumen yang digunakan dalam penelitian ini terdiri dari instrumen tes kepribadian, pedoman wawancara, dan Tugas Penyelesaian Masalah (TPM). Pengumpulan data dilakukan dengan cara wawancara berbasis tugas penyelesaian masalah kontekstual. Uji keabsahan data dilakukan dengan cara triangulasi waktu. Analisis data yang digunakan merujuk pada 3 alur analisis data dari Milles \& Huberman, yaitu reduksi data, penyajian data dan penarikan kesimpulan. Hasil dari penelitian ini dapat disimpulkan sebagai berikut. Siswa introvert menyebutkan semua informasi yang terdapat pada soal secara tepat dengan suara yang terbata-bata, sedangkan siswa ekstrovert menyebutkan semua informasi yang terdapat pada soal dengan tepat dan lancar. Kedua siswa menyelesaikan soal dengan dua cara meskipun cara-cara yang digunakan tersebut merupakan prosedur rutin yang telah lazim digunakan siswa. Dalam memeriksa kembali hasil yang diperoleh, kedua siswa mencocokkan hasil yang diperoleh dengan langkahlangkah pada metode satu dengan metode yang lain.
\end{abstract}

Kata Kunci: berpikir kreatif, penyelesaian masalah, introvert dan ekstrovert.

\section{Abstract:}

This research is a qualitative descriptive study. The research subjects consisted of female students with introverted personality and female students with extrovert personality. The instruments used in this study consisted of a personality test instrument, interview guidelines, and problem solving tasks (TPM). Data collection was carried out by means of contextual problem solving task-based interviews. The data validity test was conducted by means of time triangulation. The data analysis used refers to the 3 flows of data analysis from Milles \& Huberman, namely data reduction, data presentation and conclusion drawing. The results of this study can be concluded as follows. Introverted students mentioned all the information contained in the questions correctly in a halting voice, while extrovert students mentioned all the information contained in the questions correctly and smoothly. The two students solved the questions in two ways even though the methods used were routine procedures that were commonly used by students. In re-examining the results obtained, the two students matched the results obtained with the steps in one method with another method.

Keywords: creative thinking, problem solving, introvert and extrovert.

\section{Pendahuluan}

Matematika merupakan salah satu cabang ilmu yang selalu digunakan untuk menyelesai-

Selvia Desi Ekayana, STKIP PGRI Bangkalan

selviadesi2@gmail.com

Didik Hermanto, STKIP PGRI Bangkalan

didik.hermanto@stkippgri-bkl.ac.id

Moh Affaf, STKIP PGRI Bangkalan

mohaffaf@stkippgri-bkl.ac.id 
kan masalah-masalah dalam kehidupan sehari-hari (Didik Hermanto, 2020). Matematika memiliki peran penting dalam kegidupan seseorang, karena dengan matematika seseorang dapat meningkatkan kemampuan berfikir dan bernalar. Oleh karenanya, Pendidikan matematika selalu ada pada setiap jenjang pendidikan, yaitu mulai dari jenjang Sekolah Dasar sampai dengan jenjang Perguruan Tinggi. Qomariyah (2016) menyatakan bahwa pelajaran matematika merupakan salah satu pelajaran yang sangat penting untuk diajarkan kepada siswa. Selain hal tersebut, Keputusan Menteri Pendidikan Nasional nomor 2 tahun 2011 tentang prosedur Operasional Standar Ujian Nasional juga dijelaskan bahwa mata pelajaran matematika menjadi salah satu mata pelajaran wajib yang menjadi ukuran kelulusan Ujian Nasional. Salah satu kompetensi inti mata pelajaran matematika untuk jenjang pendidikan menengah pada kurikulum 2013 adalah mampu mengolah, menalar, menyaji, dan mencipta dalam ranah konkret dan abstrak terkait dengan pengembangan dari yang dipelajarinya di sekolah secara mandiri, dan mampu menggunakan metode sesuai kaidah keilmuan. Hal tersebut memberi makna bahwa tujuan pembelajaran matematika harus menekankan pada kemampuan berpikir siswa.

Semakin tinggi kemampuan berpikir siswa, semakin mudah bagi siswa untuk memahami dan menguasai konsep-konsep matematika yang dipelajari. Untuk membekali siswa dengan kemampuan berpikir seperti yang telah dijabarkan di atas, maka dalam pembelajaran matematika seharusnya difokuskan pada upaya untuk melatih siswa menggunakan potensi berpikir yang dimiliki. Hal senada dinyatakan oleh Soedjadi bahwa objek dasar matematika yang merupakan fakta, konsep, relasi/operasi dan prinsip merupakan hal-hal yang abstrak sehingga untuk memahaminya tidak cukup hanya dengan menghafal tetapi dibutuhkan adanya proses berpikir.

Dalam proses pembelajaran, sebaiknya siswa didorong untuk mengembangkan kemampuan berpikir. Oleh sebab itu, program pendidikan yang dikembangkan harus menekankan pada pengembangan kemampuan berpikir logis, analitis, sistematis, kritis, dan berpikir kreatif siswa. Berpikir kreatif dapat ditumbuh kembangkan melalui perancangan suatu pembelajaran yang menekankan pada pengeksplorasian kemampuan siswa. Karena pada dasarnya, masing-masing siswa mempunyai potensi kreatif yang berbeda sehingga dalam memecahkan masalah siswa diberi kesempatan untuk menyelesaikan dengan caranya sendiri. (Anton David Prasetiyo dan lailatul mubarokah, 2014).

Menurut Lindren (Yamin, 2013: 127), berpikir kreatif dapat ditumbuhkan dengan cara memberikan macam-macam kemungkinan jawaban atau pemecahan masalah berdasarkan informasi yang diberikan dan mencetuskan banyak gagasan terhadap suatu persoalan. Sejalan dengan hal tersebut, Lailatul mubarokah (2014) menyatakan bahwa, Proses berpiki individu untuk memunculkan ide baru merupakan penggabungan ide-ide sebelumnya yang belum diwujudkan atau masih dalam pemikiran. Pengertian tersebut memfokuskan banyak cara dalam memecahkan masalah dan memunculkan ide-ide baru tentang pesoalan. Setiap siswa mempunyai bakat kreatif yang berbeda sehingga proses berpikir yang terjadi dari setiap siswa dalam memecahkan masalah juga berbeda. Pengertian berpikir kreatif ini ditandai dengan munculnya ide baru sebagai hasil dari proses berpikir tersebut.

Salah satu alternatif untuk meningkatkan kemampuan berpikir siswa adalah dengan menggalakkan pertanyaan-pertanyaan yang dapat memacu proses berpikir (Hamruni (2012:104)) Kemampuan berpikir kreatif dalam matematika diperlukan untuk mendayagunakan pemikiran kreatif siswa yang bertujuan membangkitkan minat siswa dan memberi keleluasaan siswa dalam membuat pilihan, mengajukan pertanyaan dan memecahkan masalah yang bermakna. Kemampuan berpikir kreatif dalam pembelajaran matematika telah menjadi perhatian khusus bagi pemerintah hal tersebut ditunjukkan dalam permendiknas No. 22 tahun 2006, dimana salah 
satu tujuannya adalah matematika merupakan suatu alat yang mampu mengembangkan cara berpikir dan membentuk pola berpikir kreatif dalam pemecahan masalah. Kreativitas sering diabaikan oleh guru, salah satunya adalah pemecahan masalah dalam pembelajaran matematika. (Budhi \& Kartasasmita, 2015).

Selain kemampuan berpikir kreatif, keterampilan lain yang harus dimiliki siswa yaitu memecahkan masalah. Salah satu tujuan dari pembelajaran matematika yaitu kemampuan memecahkan masalah. Hal tersebut seperti yang dipaparkan dalam salah satu sasaran pembelajaran matematika di sekolah adalah agar siswa memiliki kemampuan matematika yang dapat digunakan untuk memecahkan masalah kehidupan sehari-hari (Depdiknas, 2006). Salah satu usaha yang dapat dikembangkan untuk mencapai sasaran tersebut yaitu dengan mengenalkan permasalahan matematika kepada siswa, terutama masalah yang bersifat kontekstual.

Masalah matematika kontekstual merupakan persoalan atau pertanyaan dalam matematika yang berhubungan langsung dengan dunia nyata atau berkaitan dengan obyek dalam pikiran dan tidak dapat diselesaikan berdasarkan cara yang biasa siswa lakukan Masalah matematika kontekstual juga merupakan masalah matematika yang berkaitan dengan konteks, baik berkaitan langsung dengan objek nyata atau berkaitan dengan objek abstrak seperti fakta, konsep, atau prinsip matematika. Konsep matematika muncul dari proses matematisasi yaitu dimulai dari penyelesaian yang berkaitan dengan konteks, siswa secara perlahan mengembangkan pemahaman matematis ke tingkat yang lebih formal (Hasratudin, 2010:22). Dengan memberikan masalah kontekstual, siswa secara bertahap dibimbing untuk menguasai konsep matematika. Masalah kontekstual yang digunakan dalam pembelajaran diharapkan membuat siswa tidak akan merasa abstrak terhadap permasalahan matematika, karena hal yang berawal dari kenyataan dan dekat dengan situasi kehidupan di lingkungan siswa akan lebih mudah untuk dipahami.

Terkait dengan berpikir dan penyelesaian masalah, ada beberapa aspek yang berpengaruh terhadap proses berpikir seseorang dalam penyelesaian masalah, di antaranya adalah tipe kepribadian seseorang. Penelitian yang dilakukan oleh Arini (2016) menyatakan bahwa siswa ektrovert maupun introvert mampu mengolah informasi, namun siswa ekstrovert belum mampu mengaitkan antar informasi yang ada. Subjek introvert lebih berhati-hati dan teliti di bandingkan siswa extrovert. G.C Jung (Suryabrata, 1983) menyatakan bahwa, secara umum orang ekstrovert cenderung memiliki kepribadian yang aktif, bekerja cepat tetapi tidak teliti, lebih senang bekerja kelompok dan memiliki intelegensi yang relatif rendah. Orang yang introvert memperlihatkan kecenderungan sebagai seorang pendiam, mudah tersinggung, lebih suka bekerja sendirian, tidak mudah bergaul, dan memiliki intelegensi yang relatif tinggi.

Penelitian ini difokuskan pada profil berpikir kreatif siswa dalam menyelesaikan masalah matematika kontekstual. Langkah penyelesaian masalah yang digunakan mengacu pada 4 langkah penyelesaian masalah menurut Polya. Indikator berpikir kreatif yang digunakan dalam penelitian ini merujuk pada indikator berpikir kreatif yang dikemukakan oleh Silver (1997), yaitu kefasihan, fleksibilitas, dan kebaruan. Selanjutnya indikator berpikir kreatif dalam menyelesaikan masalah berdasarkan 4 langkah penyelesaian masalah menurut Polya disajikan pada table berikut.

\section{Indikator Berpikir Kreatif Siswa dalam Menyelesaikan Masalah Berdasarkan 4 Langkah Penyelesaian} Masalah Polya 


\begin{tabular}{|c|c|c|c|}
\hline No & $\begin{array}{l}\text { Tahapan penyelesaian } \\
\text { masalah Polya }\end{array}$ & $\begin{array}{l}\text { Indikator berpikir } \\
\text { kreatif }\end{array}$ & Descriptor \\
\hline 1 & Memahami masalah & - Kefasihan & $\begin{array}{l}\text { - Menyebutkan informasi yang } \\
\text { diketahui dalam soal dengan } \\
\text { lancer tepat dan cepat } \\
\text { - Menyebutkan apa yang } \\
\text { ditanyakan pada soal dengan } \\
\text { lancer tepat dan cepat }\end{array}$ \\
\hline 2 & $\begin{array}{l}\text { Membuat rencana } \\
\text { Penyelesaian masalah }\end{array}$ & \begin{tabular}{|l} 
- Kefasihan \\
- Fleksibilitas \\
- Kebaruan
\end{tabular} & $\begin{array}{l}\text { - } \text { Menentukan metode yang akan } \\
\text { digunakan untuk } \\
\text { menyelesaikan masalah dengan } \\
\text { tepat } \\
\text { - Menentukan lebih dari satu } \\
\text { metode untuk menyelesaikan } \\
\text { masalah dengan lancer tepat } \\
\text { dan cepat } \\
\text { - Menemukan metode yang baru } \\
\text { yang belum pernah ada atau } \\
\text { dipelajari dengan lancar cepat } \\
\text { dan tepat }\end{array}$ \\
\hline 3 & $\begin{array}{l}\text { Melaksanakan } \\
\text { penyelesaian } \\
\text { masalah }\end{array}$ & $\begin{array}{l}\text { - Kefasihan } \\
\text { - Fleksibiltas } \\
\text { - Kebaruan }\end{array}$ & $\begin{array}{l}\text { - menyelesaikan masalah pada } \\
\text { soal dengan tepat } \\
\text { - pemecahan masalah pada soal } \\
\text { dengan menggunakan metode } \\
\text { lebih dari Satu } \\
\text { - menyelesaikan masalah demgan } \\
\text { metode yang belum pernah ada } \\
\text { dan yang belum pernah } \\
\text { dipelajari }\end{array}$ \\
\hline 4 & $\begin{array}{l}\text { Menguji kembali } \\
\text { jawaban yang } \\
\text { diperoleh }\end{array}$ & - Kefasihan & $\begin{array}{l}\text { Memeriksa kembali metode yang } \\
\text { digunakan sehingga metode yang } \\
\text { baru sama hasilnya dan dengan } \\
\text { metode yang biasa. }\end{array}$ \\
\hline
\end{tabular}

\section{Metode}

Penelitian ini bertujuan untuk mendeskripsikan profil berpikir kreatif siswa SMP dalam menyelesaikan masalah matematika kontekstual berdasarkan tipe kepribadian introvert dan ekstrovert. Penelitian ini merupakan penelitian deskriptif kualitatif. Subjek penelitian terdiri dari siswa perempuan berkepribadian introvert dan siswa perempuan berkepribadian ekstrovert.

Penelitian ini dilakukan di kelas VIII SMPN 2 KAMAL Pemilihan subjek diambil dilakukan dengan kriteria yang telah ditetapkan yaitu perbedaan tipe kepribadian. Pemilihan subjek dilakukan menggunakan instrumen tes tipe kepribadian yang dikembangkan oleh David Keirsey, Marilyn Bates (1984) berupa 10 butir pernyataan dengan 2 pilihan jawaban A dan B. Subjek dalam penelitian ini terdiri dari 2 siswa yang memiliki tipe kepribadian introvert dan ekstrovert, dipilih dari jenis kelamin yang sama dan berkemampuan matematika yang sama. Pemilihan subjek juga mempertimbangkan kesediaan siswa untuk menjadi subjek penelitian. Instrumen dalam penelitian ini terdiri dari instrumen utama dan instrumen bantu. Instrumen utama adalah peneliti sendiri, sedangkan instrumen pendukung/bantu yang digunakan berupa 
tes tipe kepribadian, Tugas Penyelesaian Masalah (TPM) dan pedoman wawancara. Data penelitian berupa hasil tes, hasil wawancara dan hasil dokumentasi.

Pengumpulan data dilakukan dengan cara wawancara berbasis tugas penyelesaian masalah kontekstual. Uji keabsahan data dilakukan dengan cara triangulasi waktu. Analisis data yang digunakan merujuk pada 3 alur analisis data dari Milles \& Huberman, yaitu reduksi data, penyajian data dan penarikan kesimpulan. Analisis data dilakukan dengan memperhatikan indikator berpikir kreatif yaitu kebaruan, flexibilitas dan kefasihan. Analisis dilakukan pada jawaban hasil pekerjaan subjek menyelesaikan soal TPM dan data hasil wawancara yang dilakukan sesaat setelah mengerjakan soal TPM. Keabsahan data dalam penelitian ini menggunakan triangulasi waktu. Teknik ini dilakukan dengan cara membandingkan data hasil wawancara berdasarkan TPM-1 dan data hasil wawancara berdasarkan TPM-2.

\section{Hasil dan Pembahasan}

Data hasil penelitian dikumpulkan dengan cara wawancara berbasis tugas penyelesaian masalah. Dari hasil uji kredibilitas data yang dilakukan dengan triangulasi waktu, diperoleh data yang kredibel, yang selanjutnya data tersebut dianalisis menggunakan model Miles \& Huberman (1992) yang terdiri dari tiga alur kegiatan yaitu: reduksi data, penyajian data, dan penarikan kesimpulan. Adapun tugas penyelesaian masalah yang digunakan sebagai alat untuk pengumpulan data wawancara berbasis TPM-1 dan TPM-2 adalah sebagai berikut.

\section{Tugas Penyelesaian Masalah (TPM)-1}

Rida membeli 6 buah pensil dan 3 buah penghapus dengan harga Rp.18.600,- jika ia membeli 3 buah pensil dan 5 buah penghapus, maka harganya Rp.13.500,- tentukan harga 12 pensil dan 6 penghapus!

\section{Tugas Penyelesaian Masalah (TPM)-2}

Hara membeli $4 \mathrm{Kg}$ jeruk dan $3 \mathrm{Kg}$ apel dengan harga Rp.42.500. Jika membeli $5 \mathrm{Kg}$ jeruk dan 5 $\mathrm{Kg}$ apel ia harus membayar Rp.62.500. berdasarkan 2 informasi tersebut, tentukan harga $12 \mathrm{Kg}$ jeruk dan $9 \mathrm{Kg}$ apel!

Dari hasil analisis data yang telah dilakukan, diperoleh profil berpikir kreatif siswa SMP dalam menyelesaikan masalah kontekstual yang ditinjau dari perbedaan tipe kepribadian introvert dan ekstrovert sebagai berikut.

1. Profil berpikir kreatif siswa dengan tipe kepribadian introvert dalam menyelesaikan masalah matematika kontekstual.

Dalam memahami masalah, siswa menyebutkan dan menuliskan informasi-informasi yang ada pada soal yaitu informasi yang diketahui dan yang ditanya pada soal dengan tepat meskipun dengan nada yang terbata-bata. Kemudian dalam membuat rencana penyelesaian, siswa menentukan metode yang akan digunakan untuk menyelesaikan masalah lebih dari satu metode. Dalam melaksanakan rencana penyelesaian, siswa menyelesaikan dengan dua cara meskipun dua cara yang digunakan tersebut merupakan cara rutin yang telah biasa digunakan siswa secara umum. Sedangkan dalam memeriksa kembali hasil yang diperoleh, siswa mencocokkan hasil yang diperoleh dengan langkah-langkah pada metode satu dengan metode yang lain. 
Hasil di atas dapat diartikan bahwa dalam memahami masalah, siswa kurang/tidak fasih dalam menyebutkan informasi yang ada pada soal, sedangkan dalam membuar rencana penyelesaian dan dalam melaksanakan rencana penyelesaian, siswa memiliki kefasihan dan fleksibilitas, namun belum menemukan kebaruan terkait dengan metode penyelesaian yang digunakan. dalam menyelesaikan masalah. Dalam memeriksa Kembali hasil yang diperoleh, siswa memiliki kefasihan.

2. Profil berpikir kreatif siswa dengan tipe kepribadian ekstrovert dalam menyelesaikan masalah matematika kontekstual.

Dalam memahami masalah, siswa menyebutkan dan menuliskan informasi-informasi yang ada pada soal yaitu informasi yang diketahui dan yang ditanya pada soal dengan tepat dan dengan lancar. Kemudian dalam membuat rencana penyelesaian, siswa menentukan metode yang akan digunakan untuk menyelesaikan masalah lebih dari satu metode. Dalam melaksanakan rencana penyelesaian, siswa menyelesaikan dengan dua cara meskipun dua cara yang digunakan tersebut merupakan cara rutin yang telah biasa digunakan siswa secara umum. Sedangkan dalam memeriksa kembali hasil yang diperoleh, siswa mencocokkan hasil yang diperoleh dengan langkah-langkah pada metode satu dengan metode yang lain.

Hasil di atas dapat diartikan bahwa dalam memahami masalah, siswa memiliki kefasihan dalam menyebutkan informasi yang ada pada soal, sedangkan dalam membuar rencana penyelesaian dan dalam melaksanakan rencana penyelesaian, siswa memiliki kefasihan dan fleksibilitas, namun belum menemukan kebaruan terkait dengan metode penyelesaian yang digunakan. dalam menyelesaikan masalah. Dalam memeriksa kembali hasil yang diperoleh, siswa memiliki kefasihan.

\section{Simpulan}

Siswa introvert menyebutkan semua informasi yang terdapat pada soal secara tepat dengan suara yang terbata-bata, sedangkan siswa ekstrovert menyebutkan semua informasi yang terdapat pada soal dengan tepat dan lancar. Kedua siswa menyelesaikan soal dengan dua cara meskipun cara-cara yang digunakan tersebut merupakan prosedur rutin yang telah lazim digunakan siswa. Dalam memeriksa kembali hasil yang diperoleh, kedua siswa mencocokkan hasil yang diperoleh dengan langkah-langkah pada metode satu dengan metode yang lain.

\section{Daftar Rujukan}

Agus Purnama Sari, M. S. (2017). Proses Berpikir Kreatif Siswa Dalam Memecahkan Masalah Matematika Berdasarkan Model Wallas. Jurnal Tadris Matematika, vol:10 No:1 18-32.

Anton David Prasetiyo \& Lailatul Mubarokah (2014). Berpikir Kreatif Siswa Dalam Penerapan Model Pembelajaran Berdasarkan Masalah Matematika. Jurnal Pendidikan Matematika STKIP PGRI Sidoarjo, vol:2 no:1.

Bowo Setya Budhi, G. K. (2015). Berpikir Kreatif Matematika Untuk Semua. Jakarta: Erlangga

David Keirsey, M. B. (1984). Please Understand Me Character \& Temperament Types. United States: Prometheus Nemesis Books.

Depdiknas, 2006. Kurikulum Tingkat Satuan Pendidikan. Kompetensi Dasar Pelajaran Matematika untuk Sekolah Dasar (SD)/Madrasah Ibtidaiyah (MI), Sekolah Menengah 
Pertama (SMP)/Madrasah Tsanawiyah (MTs), Sekolah Menengah Atas (SMA)/Madrasah Aliah (MA). Jakarta: Pusat Kurikulum, Balitbangdiknas, Jakarta.

Didik Hermanto (2020). “The Relational Thinking Process of Junior High School Students in Solving Contextual Mathematical Problems Based on Gender Diferenves". International Journal of Innovation, Creativity and Change. www.ijjicc.net. Special Edition: Safe Communities, 2020

Hamruni, H. (2012). Strategi Belajar Mengajar dalam Menyelesaikan Masalah Matematika Kontekstual. jurnal pendidikan matematika, 6 (9), 177-187

Hasratudin. (2010). Peningkatan Kemampuan Berpikir Kreatif Siswa SMP Melalui Pembelajaran Berbasis Masalah dengan Strategi Konflik Kognitif. Jurnal Pendidikan Matematika Vol 4 No 2,

Jarnawi Afgani Dahlan, D. J. (2016). Analisis Representasi Matematik Siswa Sekolah Dasar Dalam Penyelesaian Masalah Matematika Kontekstual. Jurusan Pendidikan Matematika FPMIPA.

Miles, M. B. dan Huberman, A. M. (1992). Analisis Data Kualitatif. UI Press, Jakarta.

Mubarokah, L. (2014). Berpikir Kreatif Siswa dalam Penerapan Model Pembelajaran Berdasarkan Masalah Matematika. Jurnal Pendidikan Matematika STKIP PGRI Sidoarjo jilid 2 http://jurnal.stkippgri-sidoarjo.ac.id/index.php/jpm/article/view/311

Nanda S. Pangestu, T. N. (2019). Proses Berpikir Kreatif Matematis Siswa Extrovert dan Introvert SMP Kelas VIII Berdasarkan Tahapan Wallas. Program Studi Pendidikan Matematika, Universitas Kristen Satya Wacana.

Polya, G. 1973. How to Solve it. 2nd Ed. Princeton University Press, ISBN 0-691-08097-6.

Qomariyah, N. (2016). Profil Pemahaman Siswa SMA Dalam Menyelesaikan Masalah Persamaan Kuadrat Ditinjau Dari Perbedaan Kepribadian Ektrovert dan Intrivert. Jurnal Apotema Vol.2 No.1, 87.

Septiana Dewi,, K. L. (2019). Profil Kemampuan Berpikir Kreatif Siswa Dalam Pemecahan Masalah Kontekstual Berdasarkan Gaya Belajar Visual. Seminar Nasional Matematika dan Pendidikan Matematika.

Silver. (1997). Kemampuan Berpikir Kreatif Siswa. Jurnal Pendidikan Matematika vol 2 no 7. ISSN2338-2996.

Siswandi, E. (2016). Analisis Kesalahan Siswa Dalam Menyelesaikan Masalah Matematika Kontekstual Pada Materi Segiempat Berdasarkan Analisis Newman Ditinjau Dari Perbedaan Gender. Jurnal Elektronik Pembelajaran Matematika, Vol.4, No.7, hal 633-643

Soedjadi, R. (2000). Kiat Pendidikan Matematika di Indonesia: Konstatasi Keadaan Masa Kini Menuju Harapan Masa Depan. Direktorat Jenderal Pendidikan Tinggi Departemen Pendidikan Nasional, Jakarta.

Suryabrata, S. (1983). Psikologi Tipe Kepribadian. Jakarta: Rajagrafindo. 
Yamin, M. (2013). Peningkatan Pemecahan Masalah Matematika Kontekstual Berbasis PISA Melalui Penerapan Problem Based Learning. jurnal Elektronik Pembelajaran Matematika Vol 2. no 193. 